\title{
Characterization of the food microbiota in ready-to- eat Mexican foods.
}

\author{
Cintia Flores-Rivas ${ }^{1}$, Fernando Hernández-Quiroz ${ }^{1}$, Loan Edel Villalobos-Flores ${ }^{1}$, Alberto Piña- \\ Escobedo ${ }^{1}$, Alejandra Chavez-Carbajal ${ }^{1}$, Khemlal Nirmalkar ${ }^{1}$ and Jaime García-Mena ${ }^{1, *}$ \\ 1 Departamento de Genética y Biología Molecular, Cinvestav Unidad Zacatenco. Av. Instituto Politécnico \\ Nacional 2508, Col. San Pedro Zacatenco, CDMX Código Postal 07360. Ciudad de México Tel: +52 (55) 5747 \\ 3800 . \\ * Correspondence:jgmena@cinvestav.mx \\ + Presented at the 1st International Electronic Conference on Microbiology, 02-30 November 2020; Available \\ online: https://ecm2020.sciforum.net/ \\ Published: 02 November 2020
}

\begin{abstract}
The ready-to-eat food microbiota are the microorganisms present in the dishes that are currently consumed during the meals. These microorganisms include those that may have a health benefit, are potentially pathogenic or have not yet been given a function. Foods suitable for consumption are not free of microorganisms, however, within the food industry only yeasts have been given a beneficial function, while other microorganisms such as filamentous fungi and bacteria have been studied for their negative effect on food. We determined the bacterial diversity in samples of high demanded freshly prepared unspoiled ready-to-eat dishes by High-throughput DNA sequencing of $16 \mathrm{~S}$ rDNA libraries. We found a great bacterial diversity where the most abundant bacterial phyla were Firmicutes, Proteobacteria, Bacteroidetes, Actinobacteria, TM7, Thermi, among others. These phyla included bacteria with remarkable abundance in some dishes. The alfa diversity analyses showed that the main dishes had the largest diversity. The beta-diversity analyses clustered the bacterial communities of soups, side plates, desserts, and beverages, and some main dishes. Based on our results we conclude that unspoiled ready-to-eat Mexican dishes contain a rich bacterial diversity, which may contribute to the organoleptic properties of the dishes without representing a sanitary risk for the consumers.
\end{abstract}

Keywords: Food; food microbiota; ready-to-eat food; High-throughput DNA sequencing

\section{Introduction}

Foods that are suitable for human consumption are not free of microorganisms, the dishes that we consume regularly, in addition to containing nutrients that contribute to our health, are full of microorganisms contributed by each ingredient [1]. The ready-to-eat food microbiota are the microorganisms present in the dishes that are currently consumed during the meals These microorganisms include those that may have a health benefit such as probiotics, or may be potentially pathogenic, in addition to others that have not yet been described or given a function [2]. It is common to describe microbial contamination in food which include pathogenic microorganisms, causing food related diseases, food spoilage or deterioration of the original food properties [3]. There are those that may have a beneficial function for the consumer as the probiotics, or even some that add desirable organoleptic properties to the food by ageing. The cheeses are an example of ingredients in the recipe of some dishes that contribute to the microbiota present in the ready-to-eat food, ingested almost three times every day by the commensals [4]. Although the microbiota which is present in the food ingredients is usually well characterized [5], the reports about the characterization of the microbiota present in ready-to-eat food are scarce [6]. In this work we explored the microbiota present in ready- 
to-eat Mexican dishes with the purpose of characterizing the bacterial communities which are ingested in the everyday feeding.

\section{Materials and Methods}

\subsection{Ready-to-eat food sampling}

A selection of approximately 35 different dishes with high consumer demand, available in the San-Pedro-Zacatenco area, in northern Mexico City $\left(19.5070^{\circ} \mathrm{N}, 99.1214^{\circ} \mathrm{W}\right)$, were aseptically collected and transported immediately to the laboratory to be processed within 30 minutes for analysis (Table 1).

\subsection{DNA extraction}

For DNA extraction, 100g of each solid dish was homogenized with $100 \mathrm{ml}$ of deionized water using a food hand blender (Braun Cat.\# MQ725) in a $500 \mathrm{~mL}$ glass beaker. An aliquot of $100 \mathrm{mg}$ of slurry or $200 \mu \mathrm{l}$ for the liquid samples was used to isolate DNA using the FavorPrep Stool Kit (Cat.\# FASTI001-1; Favorgen Biotech Corp; Ping-Tung, Taiwan), recovering the DNA in $80 \mu \mathrm{L}$ of elution buffer $(\mathrm{ddH} 2 \mathrm{O})$ and stored at $-70^{\circ} \mathrm{C}$. DNA concentration was measured using the NanoDrop 2000 spectrophotometer (Cat\# ND2000 Thermo Scientific; Massachusetts), and the DNA quality was evaluated by electrophoresis in $0.5 \%$ agarose gels. Average yield for the DNA extraction was of 37.06 $\mathrm{ng} / \mu \mathrm{L}$.

\subsection{Semiconductor DNA sequencing of V3-16S rDNA libraries}

The rDNA libraries amplifying the V3 polymorphic region of the 16S rRNA gene were prepared by PCR using barcoded primers, and semiconductor high-throughput DNA sequencing was made in Ion Torrent PGM system as previously described [7].

\subsection{Data analysis}

The data obtained from the sequencing was analyzed using the QIIME program (Quantitative Insights Into Microbial Ecology, v1.9.0) pipeline [8] to determine the relative abundance of bacteria. The alpha diversity was characterized with the Shannon, Simpson, Chao1 indices and observed species using phyloseq (v1.22.3) and ggplot2 (v3.1.0) packages in R program (v3.4.4) [9]. Beta diversity dissimilarity index was calculated by UniFrac distance metric as \% of total variability in different axes of the plot and visualized by principal coordinate analysis as described in [10].

\section{Results}

\subsection{Abundance of phyla in the ready-to-eat food.}

We found a great bacterial diversity among all studied ready-to-eat dishes (Table 1). The most abundant bacterial phyla were Firmicutes, Proteobacteria, Bacteroidetes, Actinobacteria, TM7, Thermi, among others. In the dairy products (DA) for example, the phyla Firmicutes and Proteobacteria were the most abundant except for DA1 that corresponds to a sample of Kefir which exhibited a large abundance of the phylum Proteobacteria (Fig. 1). A similar situation was observed for the side dishes (SD) where the SD3 corresponding to a sample of "chef's salad" was the one with a large relative abundance of Proteobacteria. The soups such as SO1 and SO5 (Table 1) had a large abundance of Proteobacteria and Bacteroidetes respectively, while the soups SO2, SO3, and SO4 exhibited similar large abundance of Firmicutes (Fig. 1). The main dishes MD1 to MD7 (Table 1), including dishes consisting mostly of cooked meat of chicken, pork or beef, had Firmicutes as the most abundant phylum, with the exception of MD2 (soft taco with pork rind), which had Proteobacteria the most abundant phylum. When the microbiota of the sample of desserts DE1 to DE6 were analyzed, again the Firmicutes were the most abundant phyla with exception of "sugary churros" (DE1) which contained high abundance of Actinobacteria and "chocolate bread-flan" (DE6) 
which contained Proteobacteria (Fig. 1). The three beverages we studied (Table 1) made mostly with uncooked vegetable ingredients, showed high abundance of Firmicutes (BE1 and BE3) and Proteobacteria (BE2) (Fig. 1).

\subsection{Abundance of orders, families, and genera in the ready-to-eat food.}

Among the most abundant taxa, the families Streptomycetaceae (Actinobacteria), Rikenellaceae (Bacteroidetes), and the genera Oscillospira (Firmicutes), Prevotella (Bacteroidetes), Faecalibacterium (Firmicutes), Bacteroides (Bacteroidetes), and Pseudomonas (Proteobacteria), are present in almost all the food dishes categories (Fig. 2). In the DA group, the "Kefir sample" (DA1) shows high abundance of Enterococcus (Firmicutes), Erisipelotrichaceae (Firmicutes), f Leuconostocaceae (Firmicutes), Pseudomonas (Proteobacteria), Lactococcus (Firmicutes), Acinetobacter (Proteobacteria), Lactobacillales (Firmicutes), Acetobacter (Proteobacteria), and f S24_7 (Bacteroidetes); while a "drinkable yogurt" (DA4) had high abundance of Oscillospira (Firmicutes), Streptomycetaceae (Actinobacteria), Prevotella (Bacteroidetes), Faecalibacterium (Firmicutes), Bacteroides (Bacteroidetes), Weisella (Firmicutes), Staphylococcus (Firmicutes), Rikenellaceae (Bacteroidetes), and Aeromonadaceae (Proteobacteria). Two side dishes had remarkable abundance of bacteria; for instance the "chicken salad" (SD1), had Thermus (Deinococcus-Thermus), Leuconostocaceae (Firmicutes), Acetobacteraceae (Proteobacteria), and Geobacillus (Firmicutes); while the "chef's salad" (SD3) exhibited high abundance of Staphylococcus (Firmicutes), Rikenellaceae (Bacteroidetes), Lactobacillales (Firmicutes), and Acetobacteraceae (Proteobacteria). For the case of soups, only the "chinese style rice" (SO5) had a comparable high abundance of Bacteroides (Bacteroidetes). Main dishes like "soft taco with pork rind" (MD2) had high abundance of Aeromonadaceae (Proteobacteria), Acetobacteraceae (Proteobacteria), and Geobacillus (Firmicutes), this last Firmicutes was also observed in high abundance in "Egg with chorizo" (MD3). The f S24_7 (Bacteroidetes), Acetobacteraceae (Proteobacteria), and g Geobacillus (Firmicutes), were abundant in the "Stew taco dish" (MD4); while in the same category, the "Mexican ham torta", "Mexican enfrijoladas" and "Mexican pork leg torta" carried high abundance of Weisella (Firmicutes), Thermus (Deinococcus-Thermus), Acetobacter (Proteobacteria), and Acetobacteraceae (Proteobacteria). Among the sweets, only the "Chocolate bread-Flan" carried Pseudomonas (Proteobacteria) in a high abundance comparable to the other dishes, same was observed in the beverages where only the Orange juice carried comparable high abundance of Lactococcus (Firmicutes) (Fig. 2).

\section{Discussion}

In this work we characterized the bacterial diversity present in ready-to-eat Mexican dishes, habitually consumed by adult Mexican workers. We found a remarkable bacterial diversity in the unspoiled food from which DNA was extracted after homogenization, with bacterial members of the phyla Firmicutes, Proteobacteria, Bacteroidetes, Actinobacteria, TM7, and Thermi. The Mexican healthy adult population which consume this type of food, have a fecal microbiota characterized by members of the phyla Actinobacteria, Bacteroidetes, Firmicutes, and Proteobacteria, that includes commonly members of the order Rhizobiales, Cytophagales, Nitrospirales, families f_Sphingomonadaceae, f_Cytophagaceae, f_Chitinophagaceae, f_Sphingomonadaceae, and genera such as Bulleidia, Agrobacterium, Lentzea, Nitrospira, and Sphingomonas [10]. We believe that in addition to environmental and genetic factors, every day food supplies a defined set of bacteria where some members either get established in the gut or influence the establishment of other taxa.

\section{Conclusions}

Based on our results we conclude that unspoiled ready-to-eat Mexican dishes contain a rich diversity in the bacterial community, which may contribute to the organoleptic properties of the dishes, and also might contribute to the gut microbiota in a daily basis, without representing a sanitary risk for the consumers. 
Table 1. ready-to-eat samples.

\begin{tabular}{|c|c|c|c|}
\hline ID & $\begin{array}{l}\text { Local Mexican } \\
\text { Spanish name }\end{array}$ & English name & Description \\
\hline DA1 & Leche-Búlgara & Kefir & Fermented dairy product. \\
\hline DA2 & Leche-Liconsa & Milk & Synthetic milk. \\
\hline DA3 & Leche-Saborizada & Flavored milk & Strawberry flavored milk. \\
\hline DA4 & Yogurt-bebible & Drinkable yogurt & Yogurt with a liquid consistency. \\
\hline DA5 & Yogurt-Griego & Greek style yogurt & $\begin{array}{l}\text { Yogurt with a higher amount of fat than } \\
\text { normal. }\end{array}$ \\
\hline SD1 & Ensalada-de-pollo & Chicken salad & $\begin{array}{l}\text { Vegetable salad that includes chicken for } \\
\text { protein. }\end{array}$ \\
\hline SD2 & $\begin{array}{l}\text { Ensalada-de- } \\
\text { jamón }\end{array}$ & Ham salad & $\begin{array}{l}\text { Vegetable salad that includes ham as a source } \\
\text { of protein. }\end{array}$ \\
\hline SD3 & Ensalada-del-chef & Chef's salad & $\begin{array}{l}\text { Vegetable salad with chicken, cubed cheese, } \\
\text { and boiled egg. }\end{array}$ \\
\hline SD4 & Ensalada-de-frutas & Salad with fruits & $\begin{array}{l}\text { Vegetable salad that includes fruits within its } \\
\text { ingredients. }\end{array}$ \\
\hline SD5 & $\begin{array}{l}\text { Ensalada-de- } \\
\text { broccoli }\end{array}$ & Broccoli salad & $\begin{array}{l}\text { Broccoli al vapor acompañado de verduras } \\
\text { frescas }\end{array}$ \\
\hline SO1 & Sopa-de-papa & Potato soup & Tomato broth with diced potato chunks \\
\hline $\mathrm{SO} 2$ & $\begin{array}{l}\text { Arroz-a-la- } \\
\text { Mexicana }\end{array}$ & Mexican rice & $\begin{array}{c}\text { Rice with tomato, carrot, and pea as main } \\
\text { ingredients }\end{array}$ \\
\hline $\mathrm{SO} 3$ & Crema-de-poblano & Poblano cream & Crepe prepared with poblano pepper \\
\hline $\mathrm{SO} 4$ & Sopa-de-verduras & Vegetable soup & Tomato broth with diced vegetables \\
\hline SO5 & Arroz-chino & Chinese style rice & Rice prepared as a typical oriental recipe \\
\hline MD1 & Alambre & $\begin{array}{l}\text { Beef kabob cooked } \\
\text { on a grill. }\end{array}$ & $\begin{array}{l}\text { Cubes of broiled beef, bell pepper, onion, } \\
\text { bacon, and melted cheese. }\end{array}$ \\
\hline MD2 & $\begin{array}{l}\text { Taco-de-canasta } \\
\text { con chicharrón }\end{array}$ & $\begin{array}{l}\text { soft taco with } \\
\text { pork rind. }\end{array}$ & $\begin{array}{l}\text { Steamed soft corn tortillas stuffed with fried } \\
\text { pork rind. }\end{array}$ \\
\hline MD3 & $\begin{array}{l}\text { Huevo-con- } \\
\text { chorizo }\end{array}$ & Egg with chorizo & Fried egg accompanied by Spanish sausage. \\
\hline MD4 & Taco-de-guisado & Stew taco & $\begin{array}{c}\text { Taco with Mexican tyle rice with sausages } \\
\text { with tomato. }\end{array}$ \\
\hline MD5 & Torta-de-jamón & $\begin{array}{l}\text { Mexican ham } \\
\text { torta }\end{array}$ & $\begin{array}{l}\text { Mexican bolillo (crusty roll) filled with } \\
\text { mayonnaise, avocado, ham, and basket cheese. }\end{array}$ \\
\hline MD6 & Enfrijoladas & $\begin{array}{l}\text { Mexican } \\
\text { enfrijoladas }\end{array}$ & $\begin{array}{l}\text { Fried tortillas, dipped in a slurry of refried } \\
\text { beans, and stuffed. }\end{array}$ \\
\hline MD7 & Torta-de-pierna & $\begin{array}{l}\text { Mexican pork leg } \\
\text { torta }\end{array}$ & $\begin{array}{c}\text { Mexican bolillo (crusty roll) filed with } \\
\text { mayonnaise, beans, avocado, tomato, smoked } \\
\text { pork leg. }\end{array}$ \\
\hline DE1 & $\begin{array}{l}\text { Churros- } \\
\text { azucarados }\end{array}$ & Sugary churros & $\begin{array}{l}\text { Fried-dough pastry in oil, with granulated } \\
\text { sugar. }\end{array}$ \\
\hline DE2 & Pay-de-Piña & Pineapple Pie & Pie filled with pineapple jam. \\
\hline DE3 & $\begin{array}{l}\text { Frituras de maíz } \\
\text { con limón y sal }\end{array}$ & $\begin{array}{l}\text { Corn chips with } \\
\text { lemon and salt }\end{array}$ & $\begin{array}{l}\text { Deep fried corn flour chips with lemon and } \\
\text { salt. }\end{array}$ \\
\hline DE4 & Dona glaseada & Glassed donut & $\begin{array}{l}\text { Dough fried in oil and glazed with sucrose } \\
\text { after cooking. }\end{array}$ \\
\hline DE5 & $\begin{array}{l}\text { Gorditas-de-la- } \\
\text { Villa }\end{array}$ & $\begin{array}{l}\text { Villas's soft } \\
\text { cookies }\end{array}$ & $\begin{array}{l}\text { Cornmeal (cacahuazintle), sucrose, baking } \\
\text { soda, eggs, vanilla essence, water, and } \\
\text { vegetable shortening. }\end{array}$ \\
\hline DE6 & Chocoflan & $\begin{array}{l}\text { Chocolate bread- } \\
\text { Flan }\end{array}$ & $\begin{array}{l}\text { Chocolate flavor bread with a layer of } \\
\text { sweetened egg custard with caramel topping. }\end{array}$ \\
\hline
\end{tabular}




\begin{tabular}{cccc} 
BE1 & Jugo de naranja & Orange juice & $\begin{array}{c}\text { Juice obtained from orange fruit } \\
\text { BE2 }\end{array}$ Agua de melón \\
BE3 & Jugo verde & Green juice & $\begin{array}{c}\text { Juice obtained by blending spinach, pineapple, } \\
\text { sugar to sweeten } \\
\text { orange juice and celery. }\end{array}$ \\
\hline
\end{tabular}

$\mathrm{DA}$, dairy product; $\mathrm{SD}$, side dishes; $\mathrm{SO}$, soups; $\mathrm{MD}$, main dishes; $\mathrm{DE}$, deserts; $\mathrm{BE}$, beverages. 


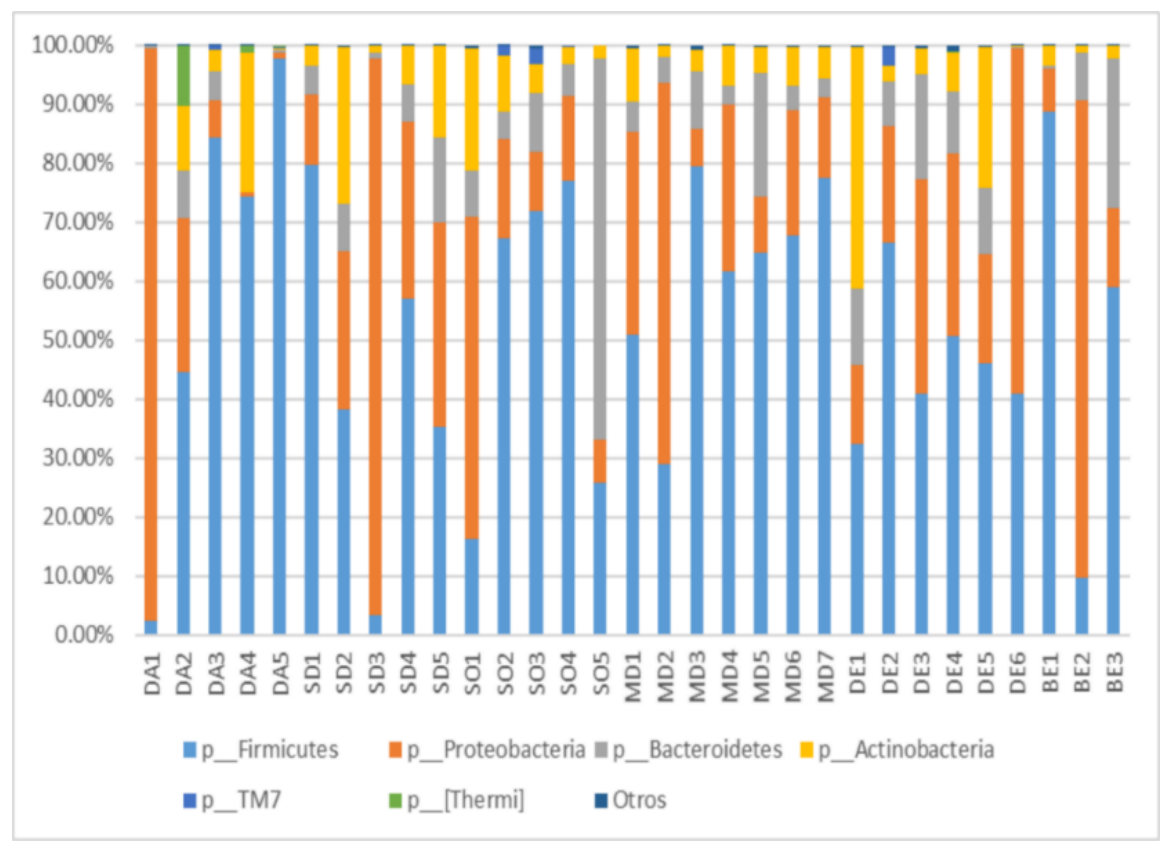

Figure 1. Relative abundance of bacterial phyla in the ready-to-eat dishes. The figure shows a bar graph of relative abundance with the most abundant bacterial phyla in the ready-to-eat dish samples. The phyla are identified with colors as shown below the graph. Others include the phylum Gemmatimonadetes, Synergistetes, and Lentisphaerae. DA, dairy product; SD, side dishes; SO, soups; $\mathrm{MD}$, main dishes; $\mathrm{DE}$, deserts; BE, beverages.

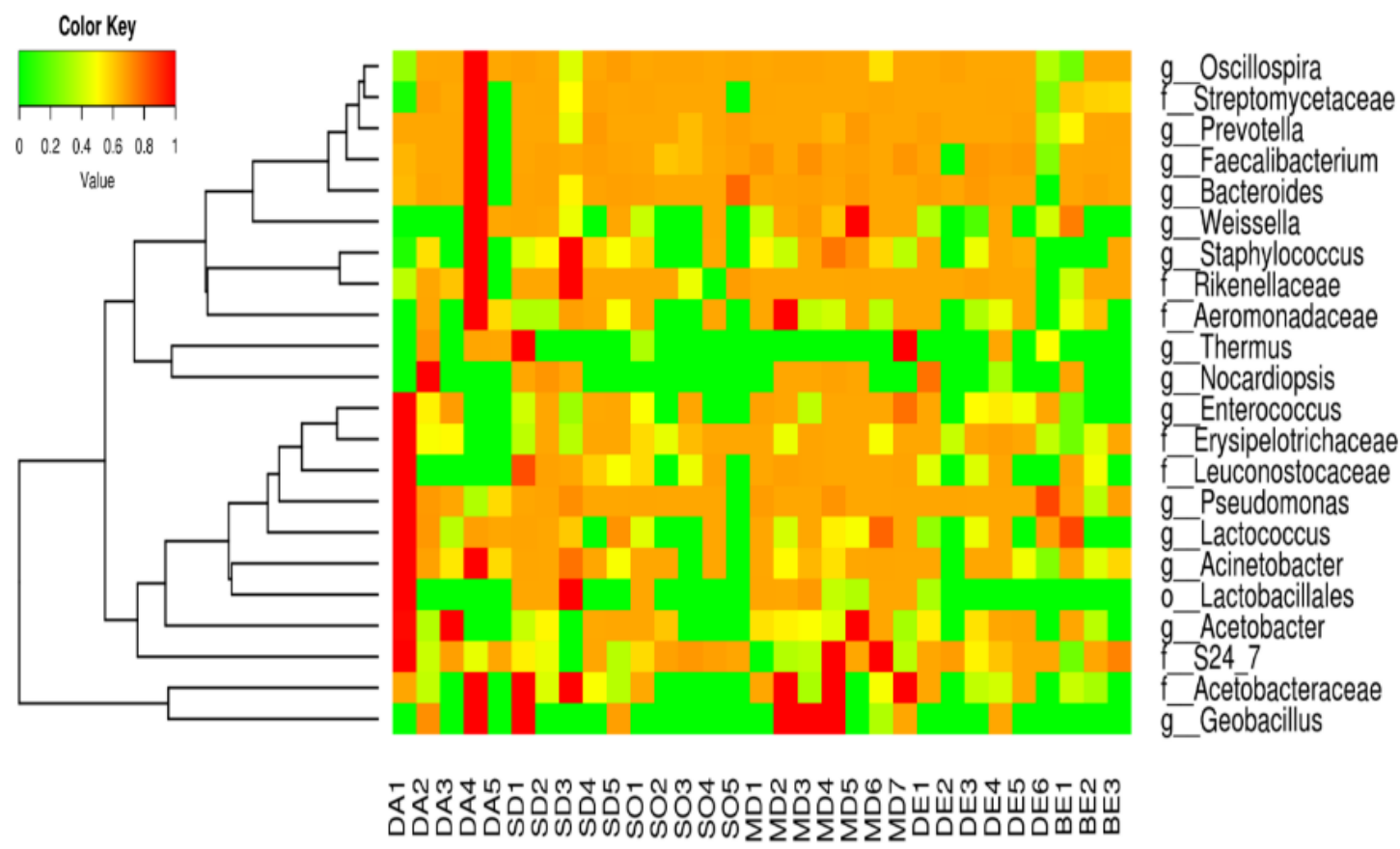

Figure 2. Relative abundance of more abundant bacterial taxa in the ready-to-eat dishes. The figure shows the food groups on the vertical axis and the horizontal axis shows the 20 most abundant bacterial genera in each group which are shared by at least $80 \%$ of the dish categories. The scale ranges from green (the least abundant), yellow (the genera with medium abundance) and red (the most abundant bacterial genera). DA, dairy product; SD, side dishes; SO, soups; MD, main dishes; DE, deserts; BE, beverages.

Author Contributions: Conceptualization, JG-M; methodology, CF-R, AP-E, AC-C, and KN; software, FH-Q, LEV-F, AC-C, and KN; validation, CF-R and JG-M; formal analysis, FH-Q, LEV-F, and KN; investigation, CF-R 
and JG-M; resources, JG-M; data curation, CF-R, FH-Q, and KN; writing-original draft preparation, CF-R and JG-M; writing - review and editing, CF-R, FH-Q, LEV-F, KN, and JG-M; visualization, JG-M; supervision, JG-M; project administration, JG-M; funding acquisition, JG-M.

Funding: This research was funded by Cinvestav, and Consejo Nacional de Ciencia y Tecnología (CONACyT) México, CONACyT-163235-INFR-2011-01.

Acknowledgments: We thank Jaime Abraham Tirado-Ramirez, Deyanira Campos-Valdez, Itzel Monserrat Zenil-Romero, Alejandra Berenice Pérez-Moreno, Fedra Judith Rambao-Valle, Paulina Melisa Rubio-Aguirre, Andrea Quetzali Cruz-Martinez, and Rodrigo García-Gutiérrez for support in the laboratory; Viridiana RosasOcegueda for administrative assistance. We thank CONACyT for Doctoral 291236 (FHQ), 336296 (LEVF), 589746 (ACC), and 589896 (KN) fellowships. JGM (19815) is a Fellow from the Sistema Nacional de Investigadores, Mexico.

Conflicts of Interest: The authors declare no conflict of interest. The funders had no role in the design of the study; in the collection, analyses, or interpretation of data; in the writing of the manuscript, or in the decision to publish the results".

\section{References}

1. Hauptmann, A. L., Paulová, P., Hansen, L. H., Sicheritz-Pontén, T., Mulvad, G., \& Nielsen, D. S. (2020). Microbiota in foods from Inuit traditional hunting. PloS one, 15(1), e0227819. https://doi.org/10.1371/journal.pone.0227819

2. Suárez-Machín, Garrido-Carralejo, N. A., (2016). Levadura Saccharomyces cerevisiae y la producción de alcohol. Revisión bibliográfica. ICIDCA. Sobre Los Derivados de La Caña de Azúcar, 50(1), $20-28$.

3. Bayona, M. A. (2009). Microbiological evaluation of food acquired in streets of a northern area of Bogotá. Revista U.D.C.A Actualidad y Divulgación Cientifica, 12(2), 9-17.

4. Murugesan, S., Reyes-Mata, M. P., Nirmalkar, K., Chavez-Carbajal, A., Juárez-Hernández, J. I., TorresGómez, R. E., García-Mena, J. (2018). Profiling of bacterial and fungal communities of Mexican cheeses by high throughput DNA sequencing. Food Research International, 113(July), 371-381. https://doi.org/10.1016/j.foodres.2018.07.023

5. Stavropoulou E, Bezirtzoglou E. Predictive Modeling of Microbial Behavior in Food. Foods. 2019 Dec 6;8(12):654. doi: 10.3390/foods8120654. PMID: 31817788; PMCID: PMC6963536.

6. Hauptmann AL, Paulová P, Hansen LH, Sicheritz-Pontén T, Mulvad G, Nielsen DS. Microbiota in foods from Inuit traditional hunting. PLoS One. 2020 Jan 14;15(1):e0227819. doi: 10.1371/journal.pone.0227819. PMID: 31935269; PMCID: PMC6959823.

7. Corona-Cervantes K, García-González I, Villalobos-Flores LE, Hernández-Quiroz F, Piña-Escobedo A, Hoyo-Vadillo C, Rangel-Calvillo MN, García-Mena J. Human milk microbiota associated with early colonization of the neonatal gut in Mexican newborns. PeerJ. 2020 May 22;8:e9205. doi: 10.7717/peerj.9205. PMID: 32509465; PMCID: PMC7247532.

8. Caporaso, J. G., Kuczynski, J., Stombaugh, J., Bittinger, K., Bushman, F. D., Costello, E. K., Fierer, N., Peña, A. G., Goodrich, J. K., Gordon, J. I., Huttley, G. A., Kelley, S. T., Knights, D., Koenig, J. E., Ley, R. E., Lozupone, C. A., McDonald, D., Muegge, B. D., Pirrung, M., Reeder, J., ... Knight, R. (2010). QIIME allows analysis of high-throughput community sequencing data. Nature methods, 7(5), 335-336. https://doi.org/10.1038/nmeth.f.303

9. McMurdie, P. J., \& Holmes, S. (2013). phyloseq: an R package for reproducible interactive analysis and graphics of microbiome census data. PloS one, 8(4), e61217. https://doi.org/10.1371/journal.pone.0061217.

10. Hernández-Quiroz, F., Nirmalkar, K., Villalobos-Flores, L. E., Murugesan, S., Cruz-Narváez, Y., RicoArzate, E., García-Mena, J. (2019). Influence of moderate beer consumption on human gut microbiota and its impact on fasting glucose and $\beta$-cell function. Alcohol. https://doi.org/10.1016/j.alcohol.2019.05.006.

Publisher's Note: MDPI stays neutral with regard to jurisdictional claims in published maps and institutional affiliations.

(C) 2020 by the authors. Submitted for possible open access publication under the terms and conditions of the Creative Commons Attribution (CC BY) license (http://creativecommons.org/licenses/by/4.0/). 